\title{
Enzymatic monitoring and control of a two-phase batch digester leaching system with integrated anaerobic filter
}

\author{
Carina Gasch ${ }^{1 *}$, Ina Hildebrandt ${ }^{2}$, Falk Rebbe ${ }^{3}$ and Isolde Röske
}

\begin{abstract}
Background: Biogas is one of the most promising regenerative energies. The simple fundamental principle underlying behind biomethanation is the conversion of biomass into biogas by microorganisms in four steps, whereby proper process regulation is crucial. Even today, the control of biogas plants is a challenging process which is based merely on physical and chemical parameters. A lack of meaningful microbiological control variables that can be quickly and easily determined locally makes it difficult for operators to react immediately if necessary.

Methods: In this study, different chemical parameters and several enzyme activities as well as their response to process disturbances were analyzed using two-phase anaerobic digestion systems with maize silage as substrate. The $\mathrm{pH}$ value, soluble chemical oxygen demand (COD), volatile fatty acids and total inorganic carbon (VFA/TIC) ratio, and biogas composition were examined using standardized cuvette or titration tests and online monitoring equipment. Hydrolase activities of esterase, amylase, protease, alanine-aminopeptidase, carboxymethyl cellulase, and xylanase were determined photometrically.
\end{abstract}

Results: Hydrolases (esterase, amylase, protease, alanine-aminopeptidase, carboxymethyl cellulase, and xylanase) represent key enzymes in the first stage of biogas generation. In normal operation, the optimum values of the specific hydrolase activities varied over retention time. This allows for a visualization of the digestion progress. Furthermore, sudden strong activity attenuation has always indicated a disruption, even before any alterations in chemical parameters were affected. Beyond that, a direct correlation between esterase activity and COD discharge could also be identified. Moreover, in terms of the utilized substrate, specific microbial enzyme activities could be discovered as quality indicators. Thus, correlations to both the age of the silage and the effective cumulative COD yield could be determined.

Conclusion: Based on our analyses, the significance of various microbial enzyme activities and their association with the biogas process was demonstrated. The photometric determination of these enzyme activities allowed a sophisticated control of biomethanation to be carried out, which requires very little effort and equipment.

Keywords: Anaerobic digestion, Two-stage, Biogas, Enzyme activity, Hydrolases, Monitoring, Correlation

\footnotetext{
* Correspondence: Carina.Gasch@tu-dresden.de

${ }^{1}$ Department of Biology, Institute of Microbiology, Dresden University of

Technology, 01062 Dresden, Germany

Full list of author information is available at the end of the article
} 


\section{Background}

Currently, the state-of-the-art energy supply is primarily carried out with fossil fuels such as oil, coal, and natural gas. In the light of limited fossil energy reserves, it is necessary to develop and improve new sustainable and future-oriented concepts of energy supply. Therefore, the proportion of renewable energies such as biogas has to increase continuously [1]. Biogas production is based on the technical usage of microbial activities, with the aim to convert organic substrates into methane as efficiently as possible. The anaerobic digestion is divided into four sub-processes - hydrolysis, acidogenesis, acetogenesis/dehydrogenation, and methanogenesis - which are characterized by different groups of microorganisms. By converting the products of the respective previous sub-process, they link the whole process [2]. During the first step, complex organic molecules (polysaccharides, proteins, and lipids) are broken down into simpler organic molecules (sugars, amino acids, and long chain fatty acids). These reactions are catalyzed by hydrolases, which are secreted by hydrolytic bacteria into the environment. Acidogenic microorganisms transform these molecules into various intermediary products (low molecular organic acids, acetate, $\mathrm{H}_{2}$, and $\mathrm{CO}_{2}$ ). The processes of hydrolysis and acidogenesis cannot be clearly delineated as they typically proceed together in metabolism [3]. Acetogenic bacteria convert the higher volatile fatty acids into acetate and hydrogen. Since the acetogenesis is only possible at a very low partial pressure of hydrogen, this partial step is coupled narrowly with methanogenesis. In this last step, two groups of methanogenic archaea produce methane from acetate or hydrogen and carbon dioxide. The first and second groups of microbes, as well as the third and fourth groups are linked closely with each other and have different requirements on the environment [2]. In the two-stage biogas plants, the biogas process is divided into hydrolysis and methanation stages by spatial separation so that these different compulsory conditions can be better adjusted to shorten the treatment time. Therefore, twostage anaerobic plants belong to the more effective systems for the conversion of solid substrates into biogas $[4,5]$. However, a disadvantage is the complicated operation and control of the process [2]. Monitoring of such biogas plants only by chemical and physical variables is apparently not sufficient. Thus, the efficiency of numerous plants is not satisfactory or even indeterminable [6]. Therefore and because biogas production is a biological process, the analysis of microbiological parameters is very important. When the substrate to be fermented consists primarily of heavily degradable herbal components, the hydrolysis represents the rate-limiting step [7]. Hence, control of this process stage is expedient. In several recent studies, the separation of the anaerobic digestion process into hydrolysis and methanogenic phases has been investigated with respect to hydrolases acting on solid biomass during anaerobic digestion [8-10]. Hydrolases are enzymes that catalyze the hydrolytic cleavage of a compound with the consumption of water. They are more or less strongly substrate specific. Therefore, the hydrolases that hydrolyze the abundant and poorly degradable substrate components are of special interest. In the case of herbal substrates, primarily, the activities of pectinase, amylase, cellulase (filter paper cellulase, $\beta$-glucosidase or carboxymethyl cellulase), xylanase, and protease were examined which catalyze the cleavage of pectin, starch, cellulose, xylan, and protein. In the analysis of hydrolase activity, Zhang as well as Parawira et al. $[8,10]$ identified the activity of free enzymes to be higher than the activity of cell-bound enzymes. This can be explained with the degradation behavior of particulate material. Compared to cell-bound enzymes, excreted enzymes have higher degradation efficiency [11] and seem to be significantly involved in the first step of the biogas process. Thus, they are responsible for the entire process speed and success. Further studies have even shown that the decomposition of structural cell components can be improved by the addition of hydrolases to the fermenter, reducing the digestion period possibly by about $30 \%$. Furthermore, the biogas yield was determined to increase up to $20 \%$ [12-14]. For an analysis of the general heterotrophic degradation activity in biological systems, the determination of the esterase activity has been proven in practice. This holds true particularly for wastewater and soil analytics $[15,16]$. For monitoring biogas plants, this analytical method has not been applied until now, although several relationships between the esterase activity and other process parameters could be identified in other bioengineered plants $[17,18]$. This makes the esterase activity also interesting for the analysis and monitoring of biogas plants.

Here the microbiological analysis of two-phase anaerobic digestion systems by different enzyme activities of hydrolases (esterase, amylase, protease, alanine-aminopeptidase, carboxymethyl cellulase, and xylanase) is reported using simple photometrical assays as well as the correlation between selected chemical parameters and the entire biogas process.

\section{Methods}

\section{Design of the study}

The experiments were carried out in two different two-stage dry-wet fermentation systems, as illustrated in Figure 1. They differ mainly in the size of the reactors. The barrel system (system I) consisted of reactors with capacities from 0.22 to $0.8 \mathrm{~m}^{3}$. The reactors of the container system (system II) ranged from 2.4 to $40 \mathrm{~m}^{3}$. The systems consisted of two to four percolators (fixed bed reactors). For a better drainage of liquid through the 


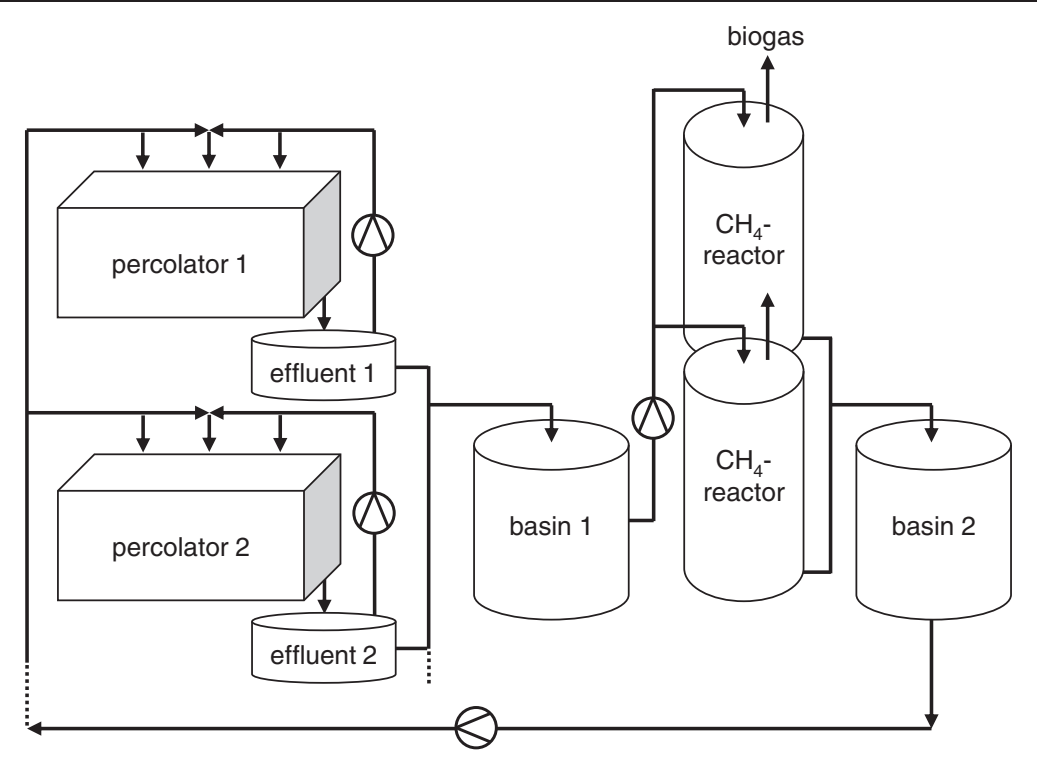

Figure 1 Scheme of the investigated two-phase anaerobic digestion system. System I consisted of $0.22 \mathrm{~m}^{3}$ percolators (fixed bed reactors) containing a separate collecting tank of the same capacity and basins 1 and 2, both with a capacity of $0.8 \mathrm{~m}^{3}$. Percolators of system $\|$ sized $40 \mathrm{~m}^{3}$, their separate collecting tank of $2.4 \mathrm{~m}^{3}$, and basins 1 and 2 had a capacity of $10 \mathrm{~m}^{3}$. The packed-bed methane reactors had a volume of $12 \mathrm{~m}^{3}$.

substrate, the substrate was supported on a perforated tray. Their effluent (hydrolyzate) could be sampled separately. The hydrolyzate was collected in a reservoir (basin 1) and fed to two packed-bed methane reactors filled with polyethylene biofilm carriers. Since the microorganisms were immobilized on the carriers, the hydraulic retention time in the methane reactors could be reduced to about 0.83 days. After the passage through the methane reactor, the process water was also collected in a reservoir (basin 2). A part of the effluent of the respective percolator as well as the process water from basin 2 was recycled to sprinkle the percolator. The percolation rate differed depending on the reactor size between $0.04 \mathrm{~m}^{3} \mathrm{~h}^{-1}$ percolator $^{-1}$ (system I) and $0.6 \mathrm{~m}^{3} \mathrm{~h}^{-1}$ percolator $^{-1}$ (system II). Both percolators and methanogenic reactors were operated at $38^{\circ} \mathrm{C}$. The methanogenic reactors were tightly sealed to maintain anaerobic conditions. In this study, chaffed maize silage with an average total solid (TS) content of $35 \%$ and volatile solid (VS) content of $96 \%$ of TS was used as substrate. The hydrolysis time, and thus the retention time of the substrate in the percolator, was between 19 and 23 days.

\section{Analytical methods}

Samples from percolators (solid samples), their direct effluent and samples from basins 1 and 2 were analyzed to detect the enzyme activities during the study period. Several chemical parameters including $\mathrm{pH}$ value, soluble chemical oxygen demand (COD), and volatile fatty acids and total inorganic carbon (VFA/TIC) ratio (content of volatile fatty acids to total inorganic carbon) were also measured in the samples. The method employed for COD measurements was analogous to EPA 410.4, US Standard Methods 5220 D and ISO 15705. VFA and TIC were measured using a two-step titration method [19]. The methane content of the methane reactors was determined using both a gas flow meter (fluidistor-gas flow meter GD 100, Esters Elektronik, Rodgau, Germany) to detect the volume and a multichannel analyzer (multichannel analyzer biogas 905, ADOS, Aachen, Germany) to examine the components of the biogas.

For analysis of the biofilm of solid samples, the biofilm had to be separated from the substrate. For this, $20 \mathrm{~g}$ of solid sample was mixed with $200 \mathrm{~mL}$ of $0.9 \%(w / v) \mathrm{NaCl}$ solution and shaken vigorously for $1 \mathrm{~min}$ by hand or incubated for $2 \mathrm{~h}$ on a horizontal shaker (150 rpm, Ströhlein Instruments HS 500, Kaarst, Germany) or sonicated for $3 \mathrm{~min}$ in an ultrasonic bath with ultrasound frequency of $35 \mathrm{kHz}$ (Sonorex Super RK 103H, Bandelin Electronic, Berlin, Germany). After allowing the solid particles to settle for some seconds, the supernatant was used for further analysis.

For the investigation of the removed biofilm from the substrate with regard to the efficiency of the methods, the total cell count of the supernatant was determined. The supernatants were fixed with a final concentration of $10 \%(w / v)$ sodium azide (VWR, Prolabo, Fontenay sous Bois, France) for at least $2 \mathrm{~h}$ at $4^{\circ} \mathrm{C}$, washed with phosphate-buffered saline $(130 \mathrm{mM} \mathrm{NaCl}, 10 \mathrm{mM}$ $\left.\mathrm{Na}_{2} \mathrm{HPO}_{4} / \mathrm{NaH}_{2} \mathrm{PO}_{4}, \mathrm{pH} 7.4\right)$ at $10,000 \times g$ for $10 \mathrm{~min}$, resuspended in phosphate-buffered saline, and fixed by addition of ethanol $(50 \% \mathrm{v} / \mathrm{v})$ for long-term fixation. The 
cells were stained using 4',6-diamidino-2-phenylindole (Merck, Darmstadt, Germany) with a final concentration of $10 \mu \mathrm{g} / \mathrm{mL}$ for $15 \mathrm{~min}$ and homogenized by sonification (Sonopuls HD2070/SH70G with probe MS73, Bandelin Electronic, Berlin, Germany). After filtration of the samples (Isopore GTBP membranes, 0.2- $\mu \mathrm{m}$ pore size, Millipore, Eschborn, Germany), the filters were mounted in Citifluor (Citifluor Ltd., Canterbury, UK) and examined by using an epifluorescence microscope (Axioskop, Carl Zeiss, Jena, Germany) equipped with the filter combination: exciter filter 360/40, dichroic mirror 400 DC LP, and emission filter D 460/50 D (Carl Zeiss, Jena, Germany). For statistical analysis, at least ten randomly selected microscopic ocular grid fields were examined for each sample.

Enzyme activities were determined by centrifuging $10 \mathrm{~mL}$ of liquid sample at $13,000 \times g$ for $10 \mathrm{~min}$. The supernatant was collected and kept on ice until use for free enzyme activity assays. The determination of all enzyme activities was carried out in triplicate, and sample blanks were taken for each sample. Photometric measurements were performed on a Hitachi U-2000 spectrophotometer (Hitachi, Tokyo, Japan). The enzyme activity was expressed in international units (IU) - micromoles of substrate transformed per unit enzyme per minute and per milliliter sample or per gram fresh weight (FW) of substrate - unless otherwise stated.

The total activity of heterotrophic microorganisms was measured based on the method of Obst by the determination of the esterase activity [20]. Supernatant with the amount of $0.5 \mathrm{~mL}$ was made up to a total volume of $9.9 \mathrm{~mL}$ with $60 \mathrm{mM}$ sodium phosphate buffer (pH 7.6). After the addition of $100 \mu \mathrm{L}$ substrate solution and $2 \mathrm{mg} / \mathrm{mL}$ fluorescein diacetate in acetone (Fluka, Buchs, Switzerland), the tubes were incubated on a shaker for $60 \mathrm{~min}$ at room temperature. After $10 \mathrm{~min}$ centrifugation at $4^{\circ} \mathrm{C}$ and $10,000 \times g$, the absorbance of the supernatant was immediately measured photometrically against the sample blank at $490 \mathrm{~nm}$. The esterase activity was calculated using a previously established standard curve with a fluorescein concentration range of 1 to $32 \mu \mathrm{mol} / \mathrm{L}$ (Fluka, Buchs, Switzerland).

Total protease activity was measured using the method of Mshandete et al. [9]. Supernatant with the amount of $1 \mathrm{~mL}$ was added to $1 \mathrm{~mL}$ preheated $0.5 \%(w / v)$ azocasein (Fluka, Buchs, Switzerland) in 200-mM Tris- $\mathrm{HCl}$ buffer (pH 7.4) and was mixed. After $1 \mathrm{~h}$ incubation at $50^{\circ} \mathrm{C}$ in a water bath, the reaction was stopped by adding $2 \mathrm{~mL}$ of $10 \%(w / v)$ trichloroacetic acid. After $10 \mathrm{~min}$ of centrifugation at $4^{\circ} \mathrm{C}$ and $10,000 \times g$, the absorbance of the supernatant was measured photometrically against the sample blank at $380 \mathrm{~nm}$. The protease activity was calculated using a previously created standard curve with the enzyme papain (Merck, Darmstadt, Germany) within a concentration range of 0.16 to $24 \mathrm{mg} / \mathrm{L}$. Therefore, $1 \mathrm{mg} / \mathrm{L}$ papain corresponds to 30 USP units. Since in most cases the USP unit is equal to the international unit or IU, the term IU was also used.

L-Alanine-aminopeptidase activity was measured using the method of Remde and Tippmann [21]. Supernatant with the amount of $2 \mathrm{~mL}$ was added to $2 \mathrm{~mL}$ of $0.1 \%(w / v)$ L-alanine-4-nitroanilide hydrochloride (Merck, Darmstadt, Germany) in $0.9 \%(w / v) \mathrm{NaCl}$ and was mixed. After $1 \mathrm{~h}$ of incubation at $30^{\circ} \mathrm{C}$ in a water bath, the reaction was stopped by adding $2 \mathrm{~mL}$ of $10 \%(w / v)$ trichloroacetic acid. Following a 10-min centrifugation at $10,000 \times g$, the absorbance of the supernatant was measured photometrically against the sample blank at $405 \mathrm{~nm}$. The L-alanine-aminopeptidase activity was calculated using a previously prepared standard curve with a 4-nitroaniline concentration range of 0.16 to $24 \mathrm{mg} / \mathrm{L}$ (Merck, Darmstadt, Germany).

Hydrolase activities of amylase, carboxymethyl cellulase, and xylanase were examined by measuring the total reducing sugars produced using dinitrosalicylate reagent method based on Miller [22]. Soluble starch of $1 \%(w / v)$ (Merck, Darmstadt, Germany) was employed as a substrate for amylase, $1 \%(w / v)$ carboxymethylcellulose (Fluka, Buchs, Switzerland) for carboxymethyl cellulase, and 0.5\% xylan from birch wood (Fluka, Buchs, Switzerland) for xylanase. All substrates were dissolved in $250 \mathrm{mM}$ potassium phosphate buffer ( $\mathrm{pH}$ 6.5). Supernatant with the amount of $150 \mu \mathrm{L}$ was added to $350 \mu \mathrm{L}$ of the pre-warmed substrate solution and mixed. After $1 \mathrm{~h}$ of incubation at $55^{\circ} \mathrm{C}$ in a water bath, the reaction was stopped by adding $750 \mu \mathrm{L}$ dinitrosalicylic acid reagent $(1 \%(w / v)$ dinitrosalicylic acid, $0.2 \%(v / v)$ phenol, $0.05 \%(w / v)$ sodium sulfite, $20 \%(w / v)$ potassium sodium tartrate, $1 \%(w / v) \mathrm{NaOH})$. After $15 \mathrm{~min}$ incubation at $99^{\circ} \mathrm{C}$ in a thermomixer (Eppendorf, Hamburg, Germany), the tubes were set on ice for $15 \mathrm{~min}$. The tubes were then centrifuged for $5 \mathrm{~min}$ at $10,000 \times g$, and the absorbance of the supernatant was measured photometrically against the sample blank at $575 \mathrm{~nm}$. The enzyme activity was calculated using both a previously established standard curve with D-glucose (Carl Roth, Karlsruhe, Germany) for the determination of the amylase and cellulose activity and a previously established standard curve with D-xylose (Adlersdorf, Berlin, Germany) for the determination of the xylanase activity in a concentration range of 3 to $20 \mu \mathrm{mol} / \mathrm{mL}$.

\section{Results and discussion}

\section{Detachment of the biofilm from the substrate}

To avoid interferences during the analysis of enzyme activities caused by the components of the substrate, a method had to be developed to separate the biofilm from the maize silage. The detachments obtained by vigorous shaking by hand, a two-hour shaking on a horizontal shaker, and a sonication method were tested. Since the detached biofilm would be used in this study to analyze the microbial activities, the total cell count 
was recorded to determine the efficiency of the methods. About $9 \times 10^{10}$ cells/g fresh weight of substrate could be removed by manual shaking, $21 \%$ more than by shaking horizontally, and $10 \%$ more than by sonication. Therefore, this method was used for further analyses.

\section{Analysis of the hydrolysis process}

Figure 2 shows the change of the $\mathrm{pH}$ value as well as the soluble COD and VFA/TIC ratio of the effluent of the percolators of system I over the retention time. The data clearly indicate that liquefaction and acidification occurred immediately after the process started. Therefore, the greatest changes could be noticed within the first week. The $\mathrm{pH}$ increased on average from 4.6 to 6.7 on day 5 and to 7.2 at the end of the observation period. The COD decreased within the first 7 days by $75 \%$, from 24,100 to $6,100 \mathrm{mg} / \mathrm{L}$. At the end of the retention time, the COD reached an average of $3,500 \mathrm{mg} / \mathrm{L}$. The VFA/ TIC ratio decreased from the third day until the end of the investigation period from 0.93 to 0.12 . A reason for the rapid decrease of the COD and the VFA/TIC ratio and the increase in the $\mathrm{pH}$ is the fast recovery of easily biodegradable substrates. In addition, the percolator, and thus its effluent, was diluted by recirculated liquid from the methane reactor [23]. The data of the samples from system II show a very similar pattern, but the COD was on average about three times higher and the VFA/TIC ratio about nine times higher (data not shown). Since the $\mathrm{pH}$ value was comparably high, the substrate appears to have a good buffer capacity [2]. Thereby, the very high COD yield and the greatly increased VFA/TIC ratio are indications of low process intensity in terms of the degradation rate of the dry organic matter. At high organic acid concentrations, the metabolism of the microorganisms is reduced and the production of the hydrolytic enzymes will be interrupted [5]. COD concentrations and VFA/TIC ratios strongly depend on the type of the system

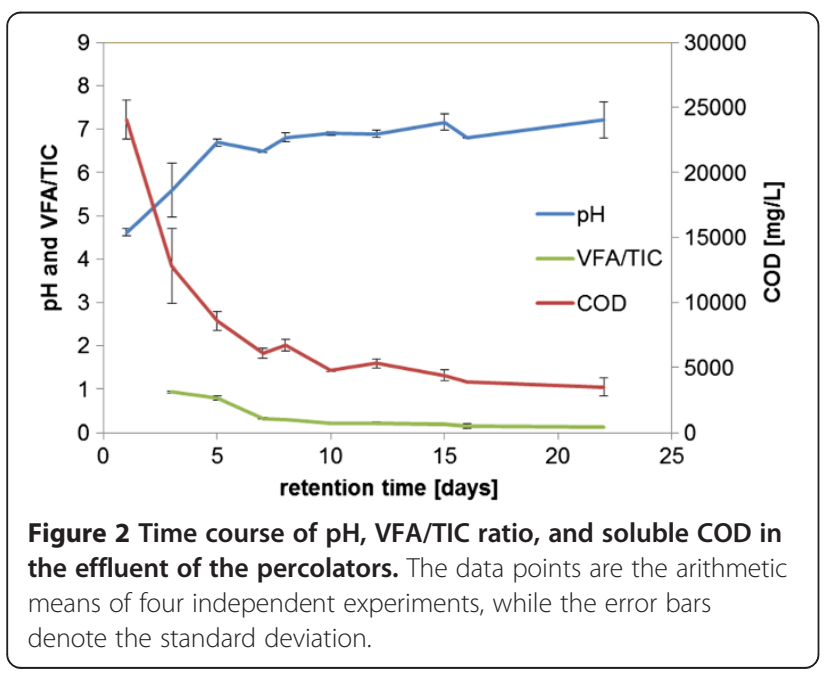

and the process control. In the literature for similar samples, COD concentrations of less than 5 to about $100 \mathrm{~g} / \mathrm{L}$ and VFA/TIC ratios between 0.24 and 7.7 have been reported $[5,23,24]$.

The activity of free enzymes was measured for a range of hydrolytic enzymes. Since hydrolysis of substrates containing a high proportion of herbal material is the rate-limiting step in the biogas process [7], the analysis of the hydrolysis rates is of great interest for its monitoring. Due to the energy-containing components of maize silage, most polysaccharides and proteins [25], the protein- and polysaccharide-degrading hydrolases, were of particular interest. In system II, both the biofilm in the percolator itself and its effluent have been investigated. As shown in earlier studies, high enzyme activities of the hydrolyzate occurred mainly during the first days of fermentation. Mshandete et al. examined several hydrolases (filter paper cellulase, carboxymethyl cellulase, $\beta$-glucosidase, amylase, pectinase, xylanase, and protease) in the hydrolysis of sisal leaf decortications residues in a comparable anaerobic digestion system. A maximum enzymatic activity within the first 7 days of fermentation was shown for this system [9]. However, it could also be observed that the activity peaks of different enzymes occurred at different times during the study period. When examining the hydrolysis of solid potato waste, Parawira et al. showed that the hydrolases (amylase, carboxymethyl cellulase, filter paper cellulase, pectinase, xylanase, and protease) may have an increased activity even after 30 to 50 days [8]. In this study, aminopeptidase, amylase, xylanase, and cellulase reached their first activity peak within the first 6 days and the second at the end of the digestion period (Figure 3). Aminopeptidase, amylase, and cellulase showed their absolute maximum with $1.2 \mathrm{IU} / \mathrm{mL}, 0.1 \mathrm{IU} / \mathrm{mL}$, and $0.08 \mathrm{IU} / \mathrm{mL}$ at the beginning and xylanase with $0.1 \mathrm{IU} / \mathrm{mL}$ at the end. The maximum protease activity was determined in the middle of the retention time with $1.7 \mathrm{IU} / \mathrm{mL}$. However, the enzyme activities of the biofilm in the percolator itself showed a different course (Figure 4). In the percolator, different sites of the heaped substrate were investigated. Depth 1 (D1) corresponds to a sampling of about 100 $\mathrm{cm}$ and depth 2 (D2) approximately $20 \mathrm{~cm}$ below the surface. Usually, the hydrolase activity of D1 was higher than that of D2 for all enzymes assayed. This can be explained by the increased dry matter content of the upper layers (data not shown) and an associated less efficient hydrolysis due to less moisture content [26]. Nevertheless, enzyme activities of both sampling points showed a similar course. Amylase, xylanase, and cellulase reached their first activity peak on day 6 and the second at the end of the digestion period. Aminopeptidase and protease exhibited a high enzyme activity on day 2 and also at the end. The absolute maximum activity of all polysaccharide-degrading enzymes could be detected at 


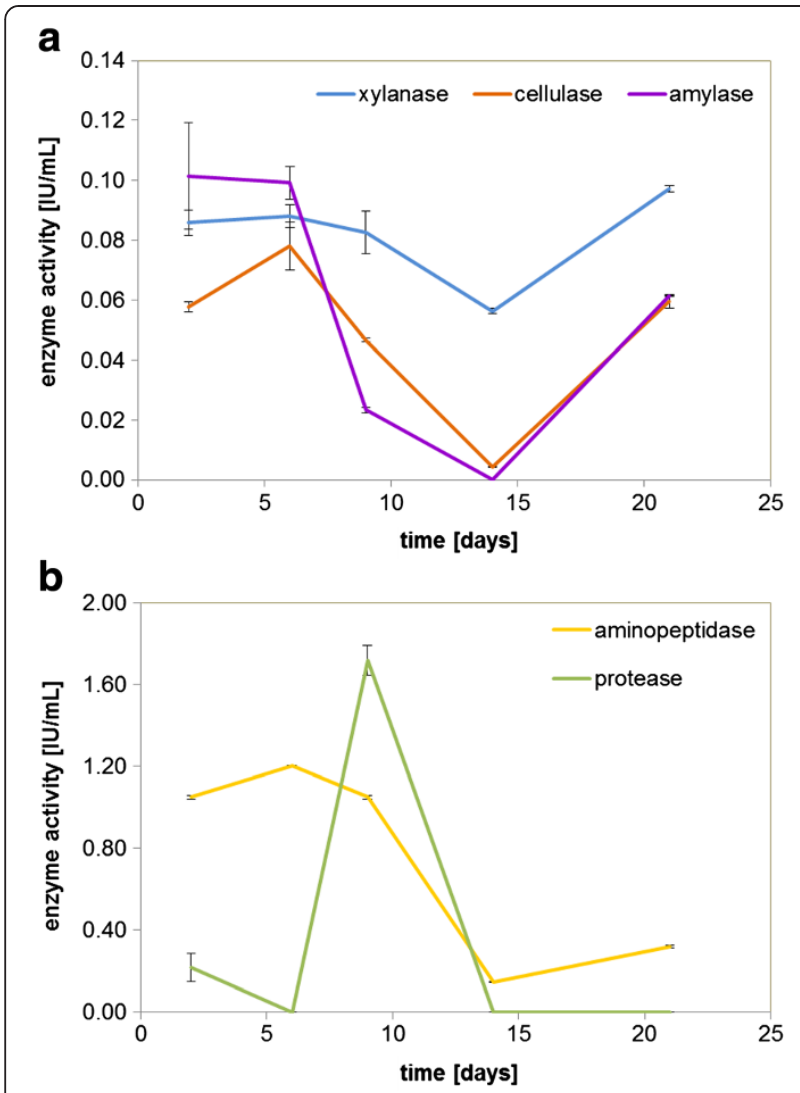

Figure 3 Time course of the enzyme activity of hydrolases in the effluent of the percolators. (a) Values of xylanase, cellulase, and amylase activities. (b) Values of aminopeptidase and protease activities. The data points are arithmetic means of two independent experiments, while the error bars denote the standard deviation.

the end of the study period with an average of $0.48 \mathrm{IU} /$ gFW of substrate for xylanase, $0.25 \mathrm{IU} / \mathrm{gFW}$ for cellulase, and $0.08 \mathrm{IU} / \mathrm{gFW}$ for amylase. Aminopeptidase showed its maximum activity at the beginning of hydrolysis with an average of $10.4 \mathrm{IU} / \mathrm{gFW}$. The course of protease activity of the samples from different depths was slightly different. The maximum of D1 was reached at the end of hydrolysis with $61.1 \mathrm{IU} / \mathrm{gFW}$, and the samples of D2 exhibited their maximum protease activity at the beginning with $23.8 \mathrm{IU} /$ gFW. Cellulose and in particular xylan are poorly degradable molecules so a high enzyme activity of cellulase and xylanase, in this case at the end of the study period, pointed to a nearly complete digestion. Since hemicelluloses, including xylan, surround the cellulose microfibrils, this polymer must be removed at least partially before the cellulose can be digested effectively [27]. This explains the increased activity of xylanase compared to cellulase. After the disintegration of the plant cell wall, the readily biodegradable starch and proteins can also be digested so that the activity of protease and amylase increased at the end of hydrolysis. Furthermore, the increased protease activity at the end of hydrolysis could be explained by the stagnating microbial
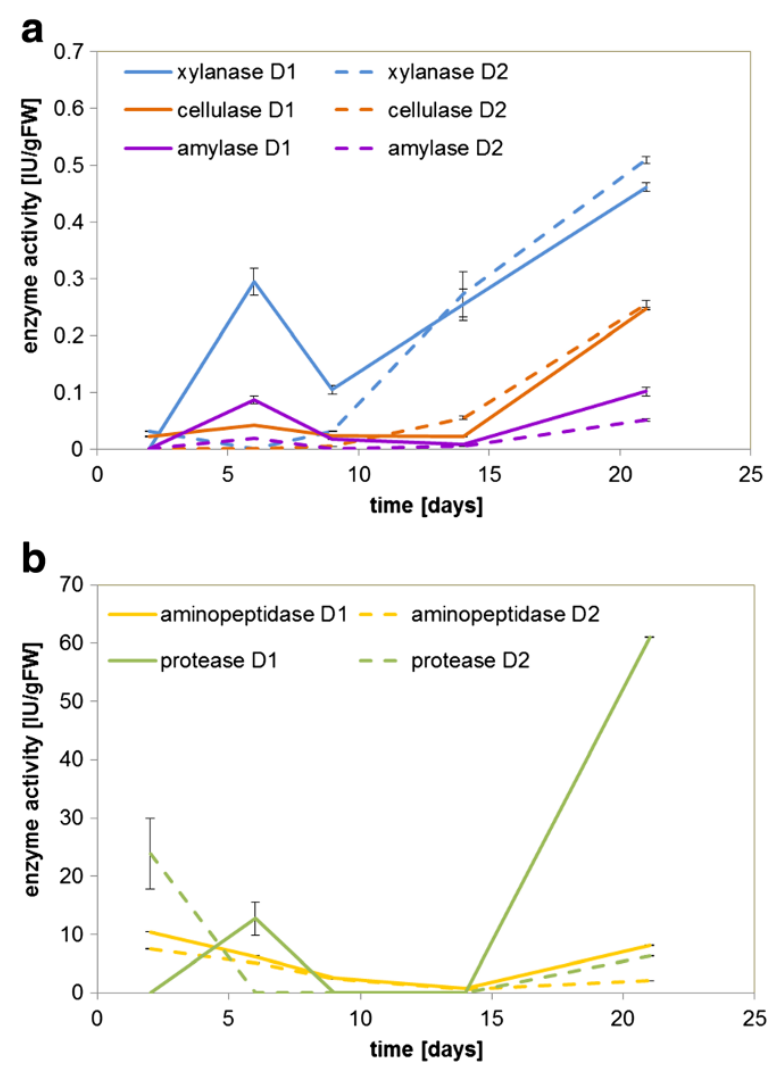

Figure 4 Time course of the enzyme activity of hydrolases of the biofilm in the percolator. (a) Values of xylanase, cellulase, and amylase activities. (b) Values of aminopeptidase and protease activity. Depth 1 (D1) corresponds to a sampling of about $100 \mathrm{~cm}$ and depth 2 (D2) to approximately $20 \mathrm{~cm}$ below the surface. The data points are arithmetic means of two independent experiments, while the error bars denote the standard deviation.

cell growth due to a lack of substrate, resulting in the digestion of protein-rich cell debris. Parawira et al. [8] also observed a renewed increase in protease activity in this time period.

As previously mentioned, the enzyme activities of hydrolyzate do not correspond to those in the percolator. In the first 10 days, a lot of hydrolases were washed out, possibly without working in the percolator. Thus, for a detailed analysis of the degradation processes in the percolator, an investigation of the biofilm on the substrate is inevitable.

\section{Visualization of disruptions in the process}

Although the enzyme activities of the percolator and the corresponding effluent do not match exactly, the detection of disturbances in the process by analysis of enzyme activities is still possible. By determining the esterase activity, the general heterotrophic activity of bacteria can be analyzed [20]. In Figure 5, the esterase activities of system II, the biofilm in the percolator and its effluent, 
are presented during a stable process and upon the occurrence of a process disruption. In stable operation, the esterase activity of the effluent increased continuously, reaching a maximum on day 13 of hydrolysis with $2.83 \mathrm{IU} / \mathrm{mL}$ and decreased again until the end of the observation period by $32 \%$. In another study period, a process disturbance occurred, which is reflected in the values of the methane content in the methane reactors (Figure 6). On day 9 of the study period, a sudden decrease in the methane content of about $8 \%$ was detected. A similar curve demonstrated both the esterase activity of the biofilm in the percolator and its effluent (Figure 5). A decrease in activity was observed at the two measuring points on day 9. The esterase activity in the percolator decreased from the initial $0.54 \mathrm{IU} / \mathrm{gFW}$ to $0.11 \mathrm{IU} /$ gFW on day 9 by $81 \%$. In the effluent of the percolator, a decrease of $56 \%$ was recorded. A high correlation $\left(r^{2}=0.76 ; p\right.$ value $\left.=2.44 \times 10^{-4} ; n=12\right)$ between the esterase activity of the process water and the detected methane content of the produced biogas could be determined (see Table 1). Therefore, the effectively
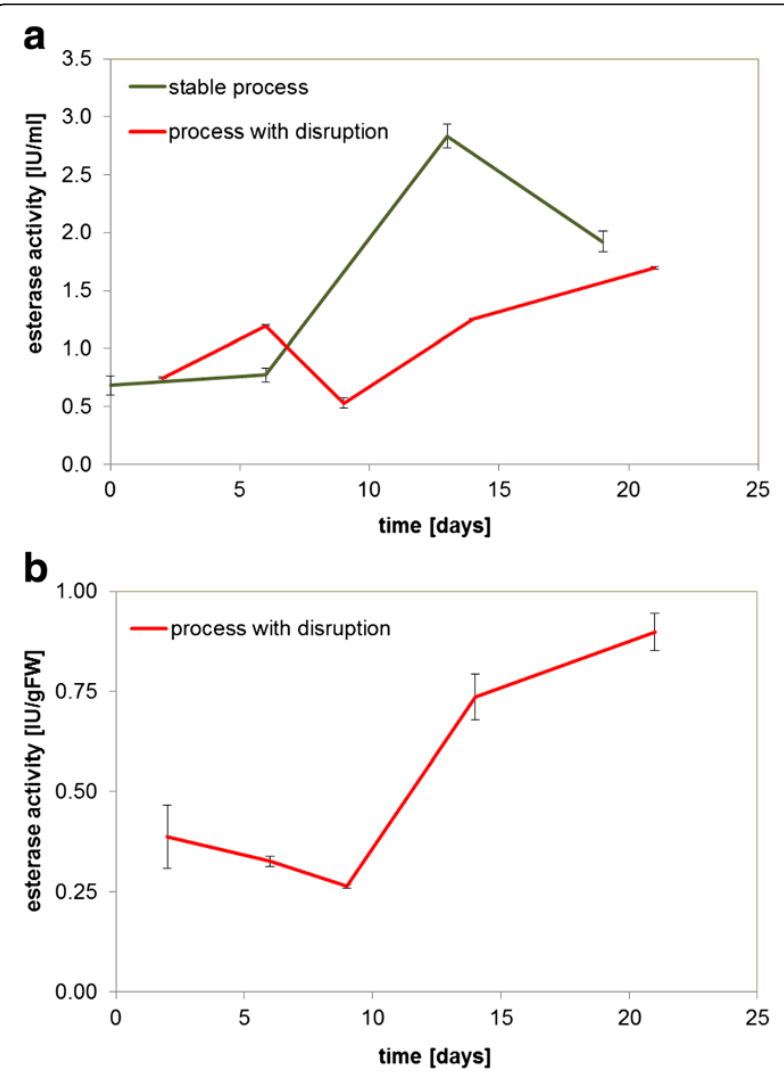

Figure 5 Time course of esterase activity during a stable process and occurrence of process disruption. (a) Time course of esterase activity of the effluent of the percolator. (b) Time course of the esterase activity of the biofilm in the percolator. Data points are arithmetic means of triplicates, while the error bars denote the standard deviation.

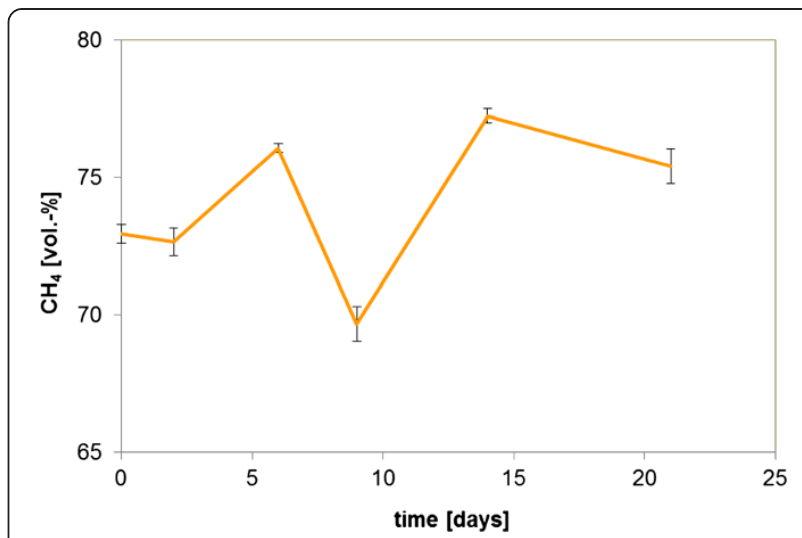

Figure 6 Methane content of the biogas from methane reactors upon occurrence of a process disruption. The data points are arithmetic means of the recorded data of the two methane reactors, while the error bars denote the standard deviation. The data were recorded in parallel with the data from Figure 5.

formed methane content is not solely dependent on the substrate composition, as it can be calculated for example by the Buswell equation [28]. In addition to chemical parameters, such as $\mathrm{pH}$ value, temperature, or increased solubility of $\mathrm{CO}_{2}$ in the liquid phase [29], microbiological parameters also influence the methane content of biogas. Since esterase activity is a sum parameter of microbial heterotrophic activity, at least in large part, all steps of the biogas process are covered. This suggests that the higher the esterase activity, the higher the microbial activity in the process water, which is associated with a higher conversion rate, and the higher the expected methane yield [9]. The detailed relationships will be discussed below.

\section{Correlations}

The energy content of a substrate, and thus the expected theoretical methane yield, can be determined using the COD. Hence, it can be considered as an important process parameter [30]. COD is the chemical oxygen demand required for the chemical conversion of the organic carbon compounds contained in the process water. These organic carbon compounds must be released first from the solid substrate by microorganisms. Therefore, the relationship between COD and the microbial activity is also interesting. In several experiments, we observed the anaerobic digestion systems I and II and analyzed the process water in terms of esterase activity and COD. As shown in Table 1, there exists a significant correlation between the esterase activity of the process water (direct effluent of the percolators, samples of basins 1 and 2) and the COD of the corresponding samples $\left(r^{2}=0.71 ; p\right.$ value $\left.=1.64 \times 10^{-50} ; n=184\right)$. The higher the esterase activity, the higher the COD. Moreover, it has been discovered that in comparison to the 
Table 1 Summary of significant correlations and corresponding statistical values

\begin{tabular}{|c|c|c|c|c|c|c|c|}
\hline \multicolumn{2}{|c|}{ Dependent } & \multicolumn{2}{|c|}{ Independent } & \multirow{2}{*}{$\begin{array}{l}\text { Sample } \\
\text { size }(n)\end{array}$} & \multirow{2}{*}{$\begin{array}{l}\text { Correlation } \\
\text { coefficient }(r)\end{array}$} & \multirow{2}{*}{$\begin{array}{l}\text { Correlation } \\
\text { coefficient } \\
\text { squared }\left(r^{2}\right)\end{array}$} & \multirow[t]{2}{*}{$p$ Value } \\
\hline Parameter & Measuring point & Parameter & Measuring point & & & & \\
\hline \multirow[t]{3}{*}{ Esterase activity (IU/mL) } & Basin $1+2$ & $\begin{array}{l}\text { Methane content } \\
\text { (vol.\%) }\end{array}$ & Methane reactor & 12 & 0.87 & 0.76 & $2.44 \times 10^{-4}$ \\
\hline & $\begin{array}{l}\text { Effluent of the } \\
\text { percolator, } \\
\text { basin } 1+2\end{array}$ & $\mathrm{COD}(\mathrm{mg} / \mathrm{L})$ & $\begin{array}{l}\text { Effluent of the } \\
\text { percolator, basin } 1+2\end{array}$ & 184 & 0.84 & 0.71 & $1.64 \times 10^{-50}$ \\
\hline & Input & $\begin{array}{l}\text { Age of the silage } \\
\text { (month) }\end{array}$ & Input & 8 & -0.89 & 0.79 & $6.28 \times 10^{-4}$ \\
\hline \multirow[t]{2}{*}{ Aminopeptidase (IU/mL) } & Input & $\begin{array}{l}\text { Age of the silage } \\
\text { (month) }\end{array}$ & Input & 6 & -0.82 & 0.68 & $4.35 \times 10^{-2}$ \\
\hline & Input & $\begin{array}{l}\text { Cumulative COD } \\
\text { yield }(\mathrm{mg} / \mathrm{L})\end{array}$ & $\begin{array}{l}\text { Effluent of the } \\
\text { percolator }\end{array}$ & 6 & 0.94 & 0.88 & $5.76 \times 10^{-3}$ \\
\hline Cellulase (IU/mL) & Input & $\begin{array}{l}\text { Cumulative COD } \\
\text { yield (mg/L) }\end{array}$ & $\begin{array}{l}\text { Effluent of the } \\
\text { percolator }\end{array}$ & 6 & 0.87 & 0.76 & $2.43 \times 10^{-2}$ \\
\hline
\end{tabular}

amount of esterase activity, a particularly high COD is discharged from the percolators within the first 3 days of fermentation. Therefore, within this period an esterase activity of $1 \mathrm{IU} / \mathrm{mL}$ corresponds to a COD discharge of approximately $25,000 \mathrm{mg} / \mathrm{L}$. When all measured values are included, except the days 0 to 3 of the direct effluent of the percolators, an esterase activity of $1 \mathrm{IU} / \mathrm{mL}$ corresponds to a COD concentration of approximately $11,300 \mathrm{mg} / \mathrm{L}$. An explanation for the high COD values in comparison to the esterase activity in the effluent of the percolators in the first days of fermentation could be an increased acid concentration. Thus, the average $\mathrm{pH}$ value in this phase of 5.6 was significantly lower than the average $\mathrm{pH}$ of the remaining process water with a value of 7.5. The VFA/TIC ratio also tended to be very high during the first days (Figure 2). This can be explained by the availability of easily degradable material in the fresh silage and a resulting strong production of organic acids like lactic acid, acetic acid, $n$-valeric acid, propionic acid, $n$-butyric acid, and other organic acids during the first few days $[3,31]$. In addition, in the first days, the organic acids produced by ensiling (mainly lactic acid) are washed out. Since nonspecific esterases show a strongly reduced activity at $\mathrm{pH}$ values below $6[32,33]$ in this phase, the ratio of esterase activity and COD is shifted. However, in general a high esterase activity in the influent of the methane reactors is an indication of a high COD and a high expected theoretical methane yield. However, a high COD in the methane reactor effluent, as compared to the COD of the influent, suggests both that it could not be converted in the reactor to methane and that there are disturbances.

Since amongst others the quality of the input is crucial for the efficiency of the whole process, the fresh maize silage was also analyzed with regard to the possible indicative parameters. The maize silages analyzed here were derived from different charges of similar good quality. Interesting relationships could be detected. As presented in
Table 1, there exists a negative correlation between the enzyme activities of esterase and aminopeptidase to the age of the maize silage $\left(r^{2}=0.79 ; p\right.$ value $=6.28 \times 10^{-4} ; n=10$ respectively $r^{2}=0.68 ; p$ value $\left.=4.35 \times 10^{-2} ; n=6\right)$. The fresher the silage, the higher the enzyme activities. The principle of the ensiling is based on a fermentation process in which anaerobic microorganisms form acids, preferably lactic acid, and the $\mathrm{pH}$ value is lowered. As a result, cell respiration, butyric acid production, and protein breakdown are minimized. Thus, under these conditions, the metabolic process is greatly limited by self-inhibition of the microorganisms and the biomass is preserved for a longer time [34]. Therefore, enzyme activity decreases depending on the storage time of the silage. If the silage is several months old and has a low enzyme activity, this points to a good quality of silage with a minimum energy loss by microbial degradation. However, when the storage conditions are poor, for example, the substrate comes in contact with oxygen which can cause a secondary aerobic decomposition [34], the microbial activity would be high.

There is also a correlation between the enzyme activity and the cumulative COD yield (Figure 7). The cumulative COD yield denotes the total soluble COD leached out from the substrate during hydrolysis. The higher the enzyme activity of aminopeptidase or cellulase, the higher the cumulative COD yield at the end of the incubation $\left(r^{2}=0.88 ; p\right.$ value $=5.76 \times 10^{-3} ; n=6$ respectively $r^{2}=0.76 ; p$ value $\left.=2.43 \times 10^{-2} ; n=6\right)$. The enzyme activity of the input in this case seems to provide an indication to the fermentability of the substrate. A reason could be the improvement of the hydrolysis process by the inoculation of adapted microorganisms which produce the corresponding hydrolases. Previous studies have demonstrated that the addition of hydrolytic enzymes to the process can enhance the degradation of substrates resulting in an increased biogas yield $[12,13]$. Among other additives, cellulase is known to 


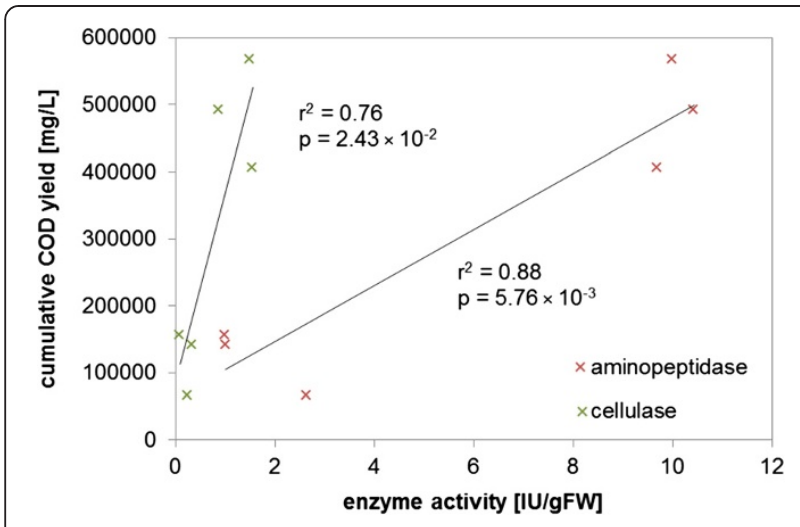

Figure 7 Correlation between enzyme activity of input and cumulative COD yield at the end of hydrolysis. The number of data points (sample size) for the correlation between aminopeptidase activity and the cumulative COD yield is 6 , the correlation coefficient squared $\left(r^{2}\right)$ is 0.88 and the $p$ value is $5.76 \times$ $10^{-3}$. The number of data points for the correlation between the cellulase activity and the cumulative COD yield is 6 , the correlation coefficient squared $\left(r^{2}\right)$ is 0.76 , and the $p$ value is $2.43 \times 10^{-2}$.

improve digestion rates and biogas yields of lignocellulosic biomass due to its capability of splitting insoluble fiber plant substrates to soluble, low molecular reducing sugars [14]. The enzyme activities of the inputs are particularly interesting because they give hints to the efficiency of ensiling and its energy potential and can thus be used as an indicator for the quality of the silage.

Figure 8 and Table 1 present an overview of the significant correlations in the analyzed systems. In the scheme of a two-phase anaerobic digestion system, the correlations determined between several parameters of different stages of the process are displayed. Thus, the determination of various enzyme activities enables the analysis of the input in terms of quality, the monitoring of the current hydrolysis process by analyzing the effluent of the percolator, and monitoring of the methane stage in terms of the efficiency of methanation. Due to the relatively small sample size $n$ (Table 1 ), these relationships should be examined in future studies for validity.

\section{Conclusions}

The control of the biogas process begins with the selection of a suitable substrate. Maize silage is still a very common substrate exhibiting high biochemical methane potential. The energy content is highly dependent on the ensiling quality. In this study, it was demonstrated that the enzyme activities of esterase and aminopeptidase permit conclusions about the age of maize silage and consequently the success of ensiling. In addition, a correlation between the aminopeptidase or cellulase activity and the cumulative COD yield has been found, which allows us to assess the biogas production potential. Thus, enzymatic analysis of the substrate permits an assessment of its quality as a biogas substrate. In two-stage biogas plants, the hydrolysis of herbal material is often the rate-limiting step. Hence, the analysis of this process phase is a possible monitoring tool. Therefore, analysis of the microbial activity is of particular importance. By determining substrate-specific hydrolases during the process, the hydrolysis progress can be observed. High xylanase and cellulase activities, for example, point to a very advanced degradation in herbal substrates. If the general microbial activity is monitored continuously, process disturbances can be detected by a drop in the measured values. A high correlation of esterase activity with COD supports this observation. Furthermore, this

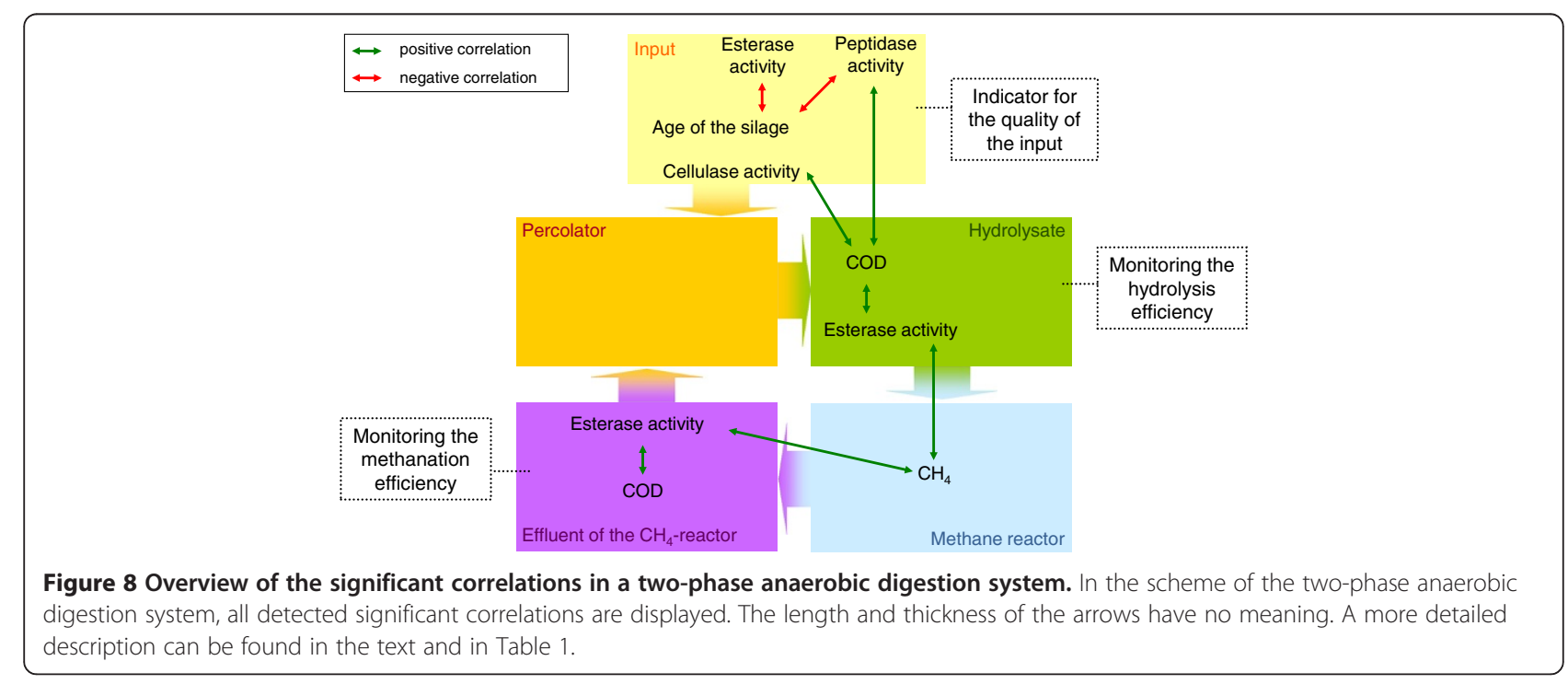


demonstrates the significance of this microbiological parameter for the biogas process.

The levels of enzyme activity can be useful for monitoring parameters during anaerobic digestion, since enzyme activities are relatively easy to measure. Moreover, it is possible to develop a simple assay that can be locally used by the operator of the biogas plant rapidly in a cuvette test. This would be a quick and inexpensive way to analyze the substrate and monitor the biogas process online and possibly to respond directly to detected process disruptions. As a consequence, monitoring of enzymatic activities enables a straightforward analysis of the biogas process, avoiding a tedious analysis of numerous chemical parameters. This allows for a novel and an extensive control of the biogas process, thus capitalizing on its full benefits.

\section{Abbreviations}

COD: Chemical oxygen demand; D1 and 2: Depth 1 and 2; FW: Fresh weight; IU: International units; TIC: Total inorganic carbon; TS: Total solids;

VFA: Volatile fatty acids; VS: Volatile solids.

\section{Competing interests}

The authors declare that they have no competing interests.

\section{Authors' contributions}

CG conceived the study, carried out all microbiological experiments, and drafted the manuscript. FR carried out the bioreactor experiments and the chemical studies. $\mathrm{IH}$ and IR conceived the study and participated in its design and coordination. All authors read and approved the final manuscript.

\section{Acknowledgments}

The authors would like to thank Dr. Axel Wobus for the constructive advice in the enzymatic studies. They are also grateful to Dr. Kerstin Röske for the constructive criticism when designing this article. The authors would also like to thank the Boden- und Grundwasserlabor $\mathrm{GmbH}$ and the Großmann Ingenieur Consult $\mathrm{GmbH}$ for their financial support of the project.

\section{Author details}

'Department of Biology, Institute of Microbiology, Dresden University of Technology, 01062 Dresden, Germany. ${ }^{2}$ BGD Boden-und Grundwasserlabor GmbH Dresden, Tiergartenstrasse 48, 01219 Dresden, Germany. ${ }^{3}$ GICON Grossmann Ingenieur Consult GmbH, Tiergartenstrasse 48, 01219 Dresden, Germany.

\section{Received: 6 May 2013 Accepted: 6 May 2013}

Published: 29 May 2013

\section{References}

1. Assmann D, Laumanns U, Uh D (2012) Renewable energy: a global review of technologies, policies and markets. Routledge, London

2. Weiland P (2010) Biogas production: current state and perspectives. Appl Microbiol Biotechnol 85(4):849-860

3. Sträuber H, Schröder M, Kleinsteuber S (2012) Metabolic and microbial community dynamics during the hydrolytic and acidogenic fermentation in a leach-bed process. Energ Sustain Soc 2(1):1-10

4. Shin HS, Han SK, Song YC, Lee CY (2001) Performance of UASB reactor treating leachate from acidogenic fermenter in the two-phase anaerobic digestion of food waste. Water Res 35(14):3441-3447

5. Busch G, Großmann J, Sieber M, Burkhardt M (2009) A new and sound technology for biogas from solid waste and biomass. Water Air Soil Poll 9(1-2):89-97

6. Schievano A, D'Imporzano G, Orzi V, Adani F (2011) On-field study of anaerobic digestion full-scale plants (part II): new approaches in monitoring and evaluating process efficiency. Biores Technol 102(19):8814-8819
7. Noike T, Endo G, Chang J-E, Yaguchi J-I, Matsumoto J-I (1985) Characteristics of carbohydrate degradation and the rate-limiting step in anaerobic digestion. Biotechnol Bioeng 27(10):1482-1489

8. Parawira W, Murto M, Read JS, Mattiasson B (2005) Profile of hydrolases and biogas production during two-stage mesophilic anaerobic digestion of solid potato waste. Process Bioch 40(9):2945-2952

9. Mshandete AM, Björnsson L, Kivaisi AK, Rubindamayugi MST, Mattiasson B (2008) Two-stage anaerobic digestion of aerobic pre-treated sisal leaf decortications residues: hydrolases activities and biogas production profile. Afr J Biochem Res 2(11):211-218

10. Zhang B, P-j H, Lü F, L-m S, Wang P (2007) Extracellular enzyme activities during regulated hydrolysis of high-solid organic wastes. Water Res 41(19):4468-4478

11. Morgenroth $E$, Kommedal R, Harremoes $P$ (2002) Processes and modeling of hydrolysis of particulate organic matter in aerobic wastewater treatment - a review. Wat Sci Tech 45(6):25-40

12. Sri Bala Kameswari K, Kalyanaraman C, Porselvam S, Thanasekaran K (2011) Enhancement of biogas generation by addition of lipase in the co-digestion of tannery solid wastes. CLEAN 39(8):781-786

13. Schimpf U, Valbuena $R$ (2009) Increase in efficiency of biomethanation by enzyme application. Bornimer Agrartechnische Berichte 68:44-56

14. Gerhardt M, Pelenc V, Bäuml M (2007) Application of hydrolytic enzymes in the agricultural biogas production: results from practical applications in Germany. Biotechnol J 2(12):1481-1484

15. Sánchez JB, Quiroga Alonso JM, Coello Oviedo MD (2006) Use of microbial activity parameters for determination of a biosolid stability index. Bioresour Technol 97(4):562-568

16. Geller A, Brauch W (1991) Handbuch mikrobiologische Bodenreinigung. Landesanstalt f, Umweltschutz BW, Karlsruhe

17. Steinbrenner C (2011) Biochemische und molekularbiologische Charakterisierung von Biofilmen des WSB ${ }^{\oplus}$-Verfahrens im Vergleich zum Belebungsverfahren unter besonderer Berücksichtigung der Nitrifikation. Dresden University of Technology, Dissertation

18. Molina-Muñoz M, Poyatos JM, Rodelas B, Pozo C, Manzanera M, Hontoria E, Gonzalez-Lopez J (2010) Microbial enzymatic activities in a pilot-scale MBR experimental plant under different working conditions. Biores Technol 101(2):696-704

19. Rieger C, Weiland P (2006) Prozessstörungen frühzeitig erkennen. BiogasJournal 4:18-20

20. Obst $U$ (1985) Test instructions for measuring the microbial metabolic activity in water samples. Fresenius J Anal Chem 321(2):166-168

21. Remde A, Tippmann P (1998) Mikrobiologische Charakterisierung aquatischer Sedimente. Methodensammlung, Oldenbourg Verlag, München

22. Miller GL (1959) Use of dinitrosalicylic acid reagent for determination of reducing sugar. Anal Chem 31(3):426-428

23. Cho JK, Park SC, Chang HN (1995) Biochemical methane potential and solid state anaerobic digestion of Korean food wastes. Biores Technol 52(3):245-253

24. Wan C, Zhou Q, Fu G, Li Y (2011) Semi-continuous anaerobic co-digestion of thickened waste activated sludge and fat, oil and grease. Waste Manage 31(8):1752-1758

25. Shao Q, Chundawat SPS, Krishnan C, Bals B, da Costa SL, Thelen KD, Dale BE, Balan V (2010) Enzymatic digestibility and ethanol fermentability of AFEXtreated starch-rich lignocellulosics such as corn silage and whole corn plant. Biotechnol Biofuels 3(12):1-10

26. Sanphoti N, Towprayoon S, Chaiprasert P, Nopharatana A (2006) The effects of leachate recirculation with supplemental water addition on methane production and waste decomposition in a simulated tropical landfill.. Environ Manage 81(1):27-35

27. Leschine SB (1995) Cellulose degradation in anaerobic environments. Annu Rev Microbiol 49:399-426

28. Buswell AM, Neave SL (1930) Laboratory studies of sludge digestion. Illinois State Water Survey, Urbana

29. Birch RR, Biver C, Campagna R, Gledhill WE, Pagga U, Steber J, Reust H, Bontinck WJ (1989) Screening of chemicals for anaerobic biodegradability. Chemosphere 19(10-11):1527-1550

30. Wheatley A (ed) (1990) Anaerobic digestion: a waste treatment technology. Elsevier, London

31. Cirne DG, Lehtomäki A, Björnsson L, Blackall LL (2007) Hydrolysis and microbial community analyses in two-stage anaerobic digestion of energy crops. J Appl Microbiol 103(3):516-527 
32. Rumsby MG, Getliffe HM, Riekkinen PJ (1973) On the association of nonspecific esterase activity with central nerve myelin preparations.

J Neurochem 21(4):959-967

33. Perez-Gilabert M, Morte A, Avila-Gonzalez R, Garcia-Carmona F (2005)

Characterization and histochemical localization of nonspecific esterase from ascocarps of desert truffle (Terfezia claveryi Chatin). J Agricult Food Chem 53(14):5754-5759

34. Schroeder JW (2004) Silage fermentation and preservation. NDSU Extension Service, Fargo, North Dakota

doi:10.1186/2192-0567-3-10

Cite this article as: Gasch et al: Enzymatic monitoring and control of a two-phase batch digester leaching system with integrated anaerobic filter. Energy, Sustainability and Society 2013 3:10.

\section{Submit your manuscript to a SpringerOpen ${ }^{\circ}$} journal and benefit from:

- Convenient online submission

- Rigorous peer review

- Immediate publication on acceptance

- Open access: articles freely available online

- High visibility within the field

- Retaining the copyright to your article

Submit your next manuscript at $\gg$ springeropen.com 